\title{
Does Competition Destroy Ethical Behavior?
}

\section{Citation}

Shleifer, Andrei. 2004. “Does Competition Destroy Ethical Behavior?” American Economic Review 94 (2) (May): 414-418. doi:10.1257/0002828041301498.

\section{Published Version}

doi:10.1257/0002828041301498

\section{Permanent link}

http://nrs.harvard.edu/urn-3:HUL.InstRepos:27867243

\section{Terms of Use}

This article was downloaded from Harvard University's DASH repository, and is made available under the terms and conditions applicable to Other Posted Material, as set forth at http:// nrs.harvard.edu/urn-3:HUL.InstRepos:dash.current.terms-of-use\#LAA

\section{Share Your Story}

The Harvard community has made this article openly available.

Please share how this access benefits you. Submit a story.

Accessibility 
NBER WORKING PAPER SERIES

DOES COMPETITION DESTROY ETHICAL BEHAVIOR?

\author{
Andrei Shleifer \\ Working Paper 10269 \\ http://www.nber.org/papers/w10269 \\ NATIONAL BUREAU OF ECONOMIC RESEARCH \\ 1050 Massachusetts Avenue \\ Cambridge, MA 02138 \\ January 2004
}

I thank Olivier Blanchard, Mihir Desai, James Hines, Jesse Shapiro, and especially Daron Acemoglu and Edward Glaeser for helpful comments. The views expressed herein are those of the authors and not necessarily those of the National Bureau of Economic Research.

(C2004 by Andrei Shleifer. All rights reserved. Short sections of text, not to exceed two paragraphs, may be quoted without explicit permission provided that full credit, including $(C)$ notice, is given to the source. 
Does Competition Destroy Ethical Behavior?

Andrei Shleifer

NBER Working Paper No. 10269

January 2004

JEL No. D41, L31, L51

\title{
ABSTRACT
}

Explanations of unethical behavior often neglect the role of competition, as opposed to greed, in assuring its spread. Using the examples of child labor, corruption, "excessive" executive pay, corporate earnings manipulation, and commercial activities by universities, this paper clarifies the role of competition in promoting censured conduct. When unethical behavior cuts costs, competition drives down prices and entrepreneurs' incomes, and thereby reduces their willingness to pay for ethical conduct. Nonetheless, I suggest that competition might be good for ethical behavior in the long run, because it promotes growth and raises incomes. Higher incomes raise the willingness to pay for ethical behavior, but may also change what people believe to be ethical for the better.

\author{
Andrei Shleifer \\ Department of Economics \\ Harvard University \\ Littauer Center M-9 \\ Cambridge, MA 02138 \\ and NBER \\ ashleifer@harvard.edu
}


This paper shows that conduct described as unethical and blamed on "greed" is sometimes a consequence of market competition. I illustrate this observation using examples of five censured activities: employment of children, corruption, excessive executive pay, corporate earnings manipulation, and involvement of universities in commercial activities. In all these examples, I show how competitive pressures lead to the spread of the censured behavior. My point is not to excuse or condemn any or all of these practices, but merely to pinpoint the crucial role of competition - as opposed to greed - in their spread.

I focus here on ethics not efficiency. The relationship between the two is complex. In many cases, ethical norms evolve to sustain cooperative behavior and to thus promote successful functioning of social institutions. For example, ethical condemnation of corruption is based on the idea that officials should not selfishly abuse public trust, and that a society functions better when its government works fairly. Likewise, the ethical norm against the employment of children is driven in part by the more general concern with abuse of the weak by the strong. When ethics promotes social cooperation, ethical behavior and efficient behavior typically go together.

In other instances, there is a mismatch between ethics and efficiency, either because ethical standards which might have had efficiency justifications long ago no longer do, or because the behavior that is ethical in some idealized society makes matters worse in the real world. For example, the ethical norm against debt or interest, which might have been justifiable a millennium ago, is clearly no longer efficient. And while child labor might be a bad idea in a world with good access to capital markets and educational opportunities, for many families in the developing world the alternative to child labor is malnutrition and decease. These examples of a mismatch suggest that behavior condemned as unethical is not always inefficient.

In still other instances, the conduct that is advertized as ethical is the result of political 
indoctrination by parochial interests or of simple confusion. For example, the ethical exhortations to "Buy American!" or to pay the "Living Wage" are underwritten by labor unions serving their members, not the public. In various times and places, tribalism, racism, anti-semitism, the hatred of the rich and other unsavory sentiments reflected the dominant ethic. In these instances, what is considered ethical is very far from what economists would consider efficient.

In some of the examples I discuss below, a credible case can be made that the conduct perceived to be unethical is also inefficient; in other examples, there is more ambiguity. My interest, however, is not to evaluate efficiency, but only to bring the crucial role of competition in the explanation of why activities morally sanctioned by the society spread.

In four of the examples I discuss, censured behavior reduces costs (in the last one, it raises revenues). I assume that the proprietor of the firm values ethical behavior, but that such behavior is a normal good. When sanctioned behavior by competitors reduces their costs, it also reduces prices in the market, and as a result the proprietor's income falls. When his income falls, so does his own demand for ethical behavior, leading to the spread of censured practices. The analysis I present is closely related to the ideas in Gary Becker's (1957) classic study of discrimination and reveals a broad range of circumstances where competition promotes censured conduct.

\section{Child Labor.}

Under many plausible scenarios, the pressures of competition bring children into the labor force. In hiring children is cheaper than hiring adults (even taking into account differences in productivity), and if one firm hires children, it can reduce prices. Its competitors must then hire children also, or be driven out of business (or, in a less extreme world, their willingness to pay for not hiring children declines when profits fall). On the other side of the market, if parents in one 
family can compel their children to work and thereby advantage themselves in competition with other families (for food or for status), then competition among families forces more children into the labor force. Either of these two forces of competition - on the demand side or on the supply side - would bring children into the labor force.

Whether or not child labor is efficient depends on a number of factors, such as whether children and/or their parents correctly value education, whether education is even available, whether capital markets are sufficiently developed that families can borrow rather than send children to work, what the family structure is, etc. Presumably, the more efficient are all these markets, the less likely we are to see children in the labor force.

\section{Corruption.}

Robert Vishny and I (1993) distinguish two kinds of corruption: with theft and without theft. In the first kind, a government official takes money in exchange for reducing the payments, such as taxes or tariffs, that the briber owes to the government. In the second kind of corruption, a government official takes additional money in exchange for giving the briber goods, such as permits, to which he is entitled without the bribe. Relative to the regime with no corruption, corruption without theft raises costs, but corruption with theft reduces costs. As a consequence, the latter kind of corruption spreads when markets are competitive. When a firm's competitor can reduce his taxes through corruption, or can import by paying lower bribes rather than higher tariffs, he can pass on his savings to consumers. In a competitive market, then, every firm must itself pay bribes or go out of business. Even if the proprietor has some rents, his willingness to pay for ethical conduct declines as his profits do, leading him to bribe. The keener is the competition, the higher is the pressure to reduce costs, and the more pervasive is corruption. 
Corruption with theft has one additional competitive advantage: both the official and the briber benefit, and neither has any incentive to report the bribe to the police. In contrast, corruption without theft raises costs, and hence the potential briber has an incentive to complain.

A further pressure comes from competition for government jobs. In some countries, positions allowing extensive bribe collection are auctioned off by senior officials. The prospective officials who will collect the bribes must pay for their jobs. This competition for jobs creates further pressure on corruption to spread: honest officials simply cannot afford the appointments, and the officials who get the jobs are the ones who can collect the most bribes. This source of competitive pressure applies to corruption both with and without theft, which might explain why corruption without theft is also pervasive, even though it raises costs.

\section{Executive Pay.}

Executive compensation has received a great deal of negative attention recently, with an emerging consensus that a large portion of what top managers get is not incentive pay but rents extracted by greedy CEOs from dysfunctional boards (Marianne Bertrand and Sendhil Mullainathan 2001, Lucian Bebchuk and Jesse Fried 2003). There is undoubtedly some truth to this view, but competition for executives has also played a role, at least during the recent stock market bubble.

Suppose that managers can extract no rents, so their pay is determined by their marginal productivity, or their contribution to the profitability of the firm. Shareholders care about maximizing the market value of the firm, which in an efficient market is the present value of expected profits. Assuming that a given manager does not contribute so much more to the firm than the next best alternative, his level of compensation would be likewise moderate.

But suppose alternatively that markets are not efficient, and expectations about future growth, 
and consequently share values, can be manipulated. Suppose some managers possess a superior ability to manipulate investor expectations, allowing them to drive up the price of company stock, at least in the short run. Such temporary price bubbles in their stock can be very valuable to shareholders: they can sell into the bubble, or their companies can acquire others using over-valued stock. In other words, managers who can create or sustain a bubble in company stock reduce its cost of equity capital. If some managers are more able than others to do that, then their compensation is determined by the competition among firms for this service.

In such a market, the value of having an executive who can reduce the cost of capital through sustaining a bubble can be enormous, and so will be his competitive pay. The starriest executives would then be allocated to companies, perhaps in the technology or other glamourous sector, where persuasion can generate a lot of shareholder value. Companies will pay up for these services, even when the executives do not contribute to profits or their growth at all.

In this example, the market for executives is perfectly competitive and efficient, yet executive talent is defined by ability to raise valuations in an inefficient financial market. In recent years, theory and evidence of stock market inefficiency have grown significantly (Shleifer 2000), especially with respect to the technology bubble (Eli Ofek and Matt Richardson 2003). The very same period saw an explosion of executive pay, especially in the high valuation firms. As the bubble collapsed, these episodes of extraordinary pay were attributed to the greed of the CEOs. Yet it seems equally plausible that shareholders during the bubble were happy to compensate these executives for promoting the bubbles in their shares.

\section{Earnings Manipulation.}

Parallel to the growth of executive pay during the technology bubble, many observers have 
pointed to an increase in a range of unsavory corporate practices, such as manipulation of earnings reported to shareholders. Companies increasingly reported pro-forma earnings - earnings not computed according to Generally Accepted Accounting Principles - on their websites (Gene D'Avolio, Efi Gildor, and Shleifer 2002). For high technology firms in particular, these earnings tend to be considerably higher than those computed in the standard fashion. Companies have also increasingly smoothed their earnings growth, used accruals to drive up earnings, and changed pension rate of return assumptions to show higher earnings (Daniel Bergstresser and Thomas Philippon 2003, Bergstresser, Mihir Desai, and Joshua Rauh 2003). At least some companies pursued downright illegal practices in reporting earnings.

There is growing evidence that these accounting tricks in fact represent a conscious attempt to manipulate shareholder beliefs. Companies tend to use these strategies to show particularly good earnings numbers right before they make acquisitions, and right before their executives exercise stock options (Bergstresser, Desai, and Rauh 2003). As this evidence has accumulated, commentators denounced the degradation of corporate standards of ethics.

The discussion of earnings manipulation has largely ignored the importance of competition for funds. During the bubble, firms faced powerful incentives to drive up their share prices, largely by reporting higher earnings growth. If earnings manipulation helps sustain a high valuation, it reduces the cost of capital, enabling companies to make acquisitions for stock, to attract better executives and workers with stock options, and even to issue new shares. For some companies, this was an issue of survival as well. Many young high technology firms, such as Amazon.com, financed their ongoing operations by issuing equity. Without creative accounting, their cost of capital might have been too high for them to survive. Likewise, for many mature firms, a high equity valuation was the matter of survival as an independent company, rather than being acquired for stock by a 
company with a higher valuation. Shleifer and Vishny (2003) show that, in the takeover market, the choice is to acquire or be acquired, and to execute the former strategy a firm needs a high valuation. In these ways, competitive pressures contributed to the rise of aggressive corporate accounting practices.

V. Commercial Activities by Universities.

In a provocative recent book, Harvard's former president Derek Bok (2003) expresses concern with commercialization of universities. According to Bok, universities are increasingly involved in highly commercial athletic programs, which generate profits but may undermine academic standards in admissions. They increasingly pursue purely commercial research efforts, which can interfere with faculty time, the selection of research priorities, and even the imperative of openness and full disclosure of results. In recent years, universities have also increasingly pursued commercial educational efforts through on-line education, which again, in Bok's opinion, may undermine core missions of research and teaching their own students.

While Bok regrets these developments, he recognizes the crucial role played by competition. Universities need resources for their core missions, such as attracting the best faculty and students, getting these faculty to teach those students, building housing and research facilities, and so on. Universities compete fiercely for faculty and students, and to the extent that profits from commercial activities give them an advantage in this competition, they embrace them. And as in the other examples I have given, competition assures the spread of commercial practices among universities.

VI. What is to be done?

I have presented five examples of activities which many people find ethically objectionable: child labor, corruption, high executive pay, earnings manipulation, and commercialization of 
education. These examples show how competition can encourage the spread of censured conduct.

What can a society do to discourage these activities? As noted earlier, it is sometimes far from obvious that discouraging them is efficient. Corruption may enable small businesses to get around unreasonable regulations, and actually encourage economic development. Child labor may improve the economic circumstances of both children and their families in places where the feasible alternatives are hunger and malnutrition. High levels of executive pay may allocate the most talented managers to growing young firms. Some technology entrepreneurs argued that conventional accounting harmed their companies as investors failed to understand the temporary nature of their losses, and that therefore some freedom of accounting choice was essential for accuracy. And commercialization of universities might enable them to better discharge their core duties.

We can think of (at least) three strategies for curtailing unethical conduct, involving increasing amounts of coercion: long run market pressure, moral suasion, and government regulation. Some economists express an optimistic view that, in the long run, markets cure the problems we discussed. If public opinion really turns against child labor, firms that do not hire children will be able to charge higher prices. Firms which pay executives to pump up their stock, or manipulate their earnings, will face eventual investor disappointment and a higher, not lower, cost of capital. And universities that over-commercialize their activities will lose serious faculty and students.

These arguments about long run competition are not compelling. While public opinion may exert pressure in the long run, in the short run people want cheaper shoes, and most do not care who makes them. Emerging market subcontractors refusing to hire children counting on the tide in consumer sentiment for adult-made shoes, surely cannot survive. Likewise, firms that do not manipulate their earnings or compete for glamourous executives might not survive as independent entities long enough for reality to intervene. Finally, universities that eschew commercialism may 
find themselves too far behind academically to catch up. Competition may take too long to work, and even in the long run it need not work to promote ethical values.

A more aggressive strategy is moral suasion. One can try to convince companies - through persuasion and perhaps even boycotts - not to hire children, not to manipulate earnings, and not to pay too much to executives. Derek Bok clearly follows this approach in urging university administrators to slow down commercialization.

Moral suasion is likely to work better when competition is less keen. Protests can discourage Nike - with its rents from its name - from hiring children, either on its own or through subcontractors. Moral suasion can slow down commercialization among the wealthiest universities, which have significant endowments. The richer the competitor, the more it will pay for being ethical. But the trouble with moral suasion is that it can rarely stand up to the forces of competition when competitors have no rents. This is precisely the reason why the phenomena I describe are so pervasive. Even if managers, boards, or shareholders of companies are convinced that it is bad to manipulate earnings, pay a lot to executives, or hire children in developing countries, their discretion is severely circumscribed by the imperative of commercial survival. Even in the richest private universities, competition for faculty and students is sufficiently keen to at best delay the advance of commercialization. In most cases, then, moral suasion will not stop the pressures of competition.

What about government regulation? Governments often restrict entry, or ban cost reducing practices that are deemed unethical. Governments prohibit many kinds of corruption, and impose criminal penalties on those who are caught. In developed countries, governments ban child labor. In most countries, governments regulate earnings reporting and are beginning to regulate executive pay. Finally, even in the U.S. where universities are private, their not-for-profit status severely limits their pursuit of commercial activities. In all the cases we discussed, the government is involved, 
although the nature of its involvement varies.

But here again, one should not expect too much success from regulation, especially where the state's enforcement powers are limited. Even if the government pursues benevolent policies (which is far from universal), when it battles against cost reducing competition, it is likely to lose. This is partly why corruption, child labor, and unsavory accounting practices remain pervasive.

If this analysis is complete, it leads to a fairly depressing conclusion. Globalization and the victory of laissez-faire economics has made competition keener in many countries and markets around the world. Does this imply that unethical conduct is also becoming more pervasive?

The answer, I believe, is NO, for two separate reasons. First, competition is the fundamental source of technological progress and wealth creation around the world. The very same market forces that might encourage unethical conduct, also motivate firms to innovate and create new products, leading to economic growth. As societies grow richer, their willingness to pay for ethical behavior - through both government enforcement and private choice - increases as well. As a consequence, both moral and regulatory sanctions work better in the richer countries, leading to more ethical behavior. Second, as Benjamin Friedman (2004) demonstrates, as societies grow richer their views of what is ethical change as well. More universalist ethics that emphasize cooperation and inclusion replace the more tribal and parochial beliefs. As I have argued in the introduction, the ethics of cooperation is much more likely to coincide with objective notions of efficiency. For both of these reasons - the increased willingness to pay for ethical behavior and the improving match between ethics and efficiency - competition is likely to promote ethical behavior in the long run. 


\section{References.}

Bebchuk, Lucian and Jesse Fried. "Executive Compensation as an Agency Problem.” Journal of Economic Perspectives, 2003, 17(3), pp.71-92.

Becker, Gary. The Economics of Discrimination. Chicago: Univ. of Chicago Press, 1957.

Bergstresser, Daniel, Mihir Desai, and Joshua Rauh. "The Gerstner Effect." Mimeo, Harvard Business School, 2003.

Bergstresser, Daniel, and Thomas Philippon. "CEO Incentives and Earnings Management." Mimeo, Harvard Business School, 2003.

Bertrand, Marianne and Sendhil Mullainathan. "Are CEOs Rewarded for Luck? The Ones without Principals are.” Quarterly Journal of Economics, 2001, 116(3), pp. 901-932.

Bok, Derek. Universities in the Marketplace: The Commercialization of Higher Education. Princeton: Princeton University Press, 2003.

D’Avolio, Gene, Efi Gildor, and Andrei Shleifer. “Technology, Information Production, and Market Efficiency," in Economic Policy For The Information Economy, A Symposium Sponsored by The Federal Reserve Bank of Kansas City, 2002.

Friedman, Benjamin. The Moral Consequences of Economic Growth. Forthcoming, 2004.

Mullainathan, Sendhil and Andrei Shleifer. "The Market for News.” Mimeo, Harvard, 2003.

Ofek, Eli and Matt Richardson. "DotCom Mania: The Rise and Fall of Internet Stocks." Journal of Finance, 2003, $\underline{58(3), ~ p p . ~ 1113-1138 . ~}$

Shleifer, Andrei. Inefficient Markets. Oxford: Oxford University Press, 2000.

Shleifer, Andrei and Robert Vishny. "Corruption.” Quarterly Journal of Economics, 1993, 108(3), pp. 599-617, 1993.

Shleifer, Andrei and Robert Vishny. "Stock Market Driven Acquisitions." Journal of Financial Economics, 2003, 70(3), pp. 295-311. 